\title{
Status dan perkembangan resistensi Aedes aegypti (Linnaeus) (Diptera: Culicidae) strain Bandung, Bogor, Makassar, Palu, dan VCRU terhadap insektisida permetrin dengan seleksi lima generasi
}

\author{
Status and development of resistance of Aedes aegypti (Linnaeus) \\ (Diptera: Culicidae) strains Bandung, Bogor, Makassar, Palu, and \\ VCRU upon selection with permethrin in five generations \\ Yerslin Mantolu ${ }^{1}$, Kustiati ${ }^{2,3}$, Trisnowati Budi Ambarningrum ${ }^{2,4}$, \\ Sri Yusmalinar', Intan Ahmad ${ }^{2 *}$ \\ ${ }^{1}$ Sekolah Menengah Atas Negeri 2 Petasia \\ Jalan Wulanderi No. 100, Desa Korololama, Kecamatan Petasia \\ Kabupaten Morowali Utara, Sulawesi Tengah 94671 \\ ${ }^{2}$ Sekolah Ilmu dan Teknologi Hayati, Institut Teknologi Bandung \\ Jalan Ganesha No. 10, Bandung 40132 \\ ${ }^{3}$ Jurusan Biologi, Fakultas Matematika dan Ilmu Pengetahuan Alam, Universitas Tanjungpura \\ Jalan Ahmad Yani, Pontianak 78124 \\ ${ }^{4}$ Fakultas Biologi, Universitas Jenderal Soedirman \\ Jalan Dr. Soeparno No. 63, Purwokerto 53122 \\ (diterima Oktober 2014, disetujui Februari 2015)
}

\begin{abstract}
ABSTRAK
Aedes aegypti (Linnaeus) (Diptera: Culicidae) merupakan serangga vektor utama penyakit demam berdarah. Di Indonesia, cara yang selama ini terbukti efektif untuk mengendalikan Ae. aegypti adalah dengan menggunakan insektisida terutama piretroid, seperti permetrin. Meskipun permetrin telah digunakan sejak tahun 1980an, informasi mengenai status dan perkembangan resistensi Ae. aegypti terhadap permetrin masih terbatas dan perlu dilakukan pembaharuan data. Penelitian ini dilakukan menggunakan metode uji standar WHO bertujuan untuk mengetahui status dan perubahan tingkat resistensi Ae. aegypti strain lapangan, yaitu Palu, Makassar, Bandung, Bogor, dan strain rentan (VCRU) yang diseleksi dengan permetrin selama lima generasi. Hasil penelitian menunjukkan bahwa semua strain lapangan telah resisten terhadap permetrin dengan tingkat resistensi tinggi (nilai $\mathrm{RR}_{50}$ yang berkisar antara 10,5 dan 25,7). Strain Bandung memperlihatkan $\mathrm{RR}_{50}$ tertinggi $(25,7)$ dan terendah pada strain Makassar (10,5). Lima strain yang diseleksi mengalami kenaikan tingkat resistensi 5-18 kali lebih tinggi pada F5 dibandingkan dengan parentalnya. Pengetahuan mengenai status resistensi pada area tertentu ditambah dengan pemahaman tentang kecepatan terjadinya resistensi, dapat digunakan untuk merancang program pengendalian vektor yang lebih baik.
\end{abstract}

Kata kunci: Aedes aegypti, permetrin, resistensi, tekanan seleksi

\begin{abstract}
Aedes aegypti (Linnaeus) (Diptera: Culicidae) is the main vector of dengue fever. In Indonesia, insecticides, especially pyrethroids, such as permethrin, have been effectively used to control $A e$.
\end{abstract}

*Penulis korespondensi: Intan Ahmad. Sekolah Ilmu dan Teknologi Hayati, Institut Teknologi Bandung, Jalan Ganesha No. 10, Bandung 40132 Tel: 022-2511575, Faks: 022-2515033, Email: intan@itb.ac.id 
aegypti. Notwithstanding that permethrin has been used since 1980s, information regarding the status and development of resistance of Ae. aegypti to permethrin is still limited and need further update. This study was conducted using the WHO standard test method. The aims was to determine the resistance status, and changes in resistance level of four field strains (Palu, Makassar, Bandung, Bogor) and susceptible strain (VCRU) of Ae. aegypti after the selection with permethrin for five generations. The results showed that resistance status of all field strains to permethrin were considered as high. The value of $\mathrm{RR}_{50}$ ranged between 10.5 to 25.7 fold. Bandung strain had the highest value of $\mathrm{RR}_{50}(22.5$ fold $)$, while Makassar strain had the lowest value of $\mathrm{RR}_{50}(10.5$ fold $)$. The fifth generation (F5) of five selected Ae. aegypti strains had the level of resistance 5 to 18 times higher than their parental. Knowledge of resistance status in a given area accompanied with the understanding about the development of resistance can be used to design a better vector management.

Key words: Aedes aegypti, insecticide selection, permethrin, resistance

\section{PENDAHULUAN}

Aedes aegypti (Linneaus) adalah vektor utama penyebab penyakit demam berdarah dengue (DBD). Kasus DBD di Indonesia masih sangat tinggi, bahkan tertinggi di ASEAN. Pada tahun 2013 dilaporkan sebanyak 112.511 kasus dan 871 kasus meninggal. Sampai pertengahan Desember 2014, walau terjadi penurunan dibandingkan dengan tahun sebelumnya, tercatat 71.668 kasus, dengan 641 kasus meninggal (Kemenkes RI 2015). Meskipun pada tiga bulan terakhir tahun 2015 terjadi penurunan kasus kesakitan dan kematian akibat penyakit DBD, tetapi hingga akhir Januari 2016 tercatat kejadian luar biasa (KLB) penyakit DBD di 9 kabupaten dan 2 kota dari 7 provinsi di Indonesia. Sebanyak 492 kasus dengan jumlah kematian 25 kasus terjadi dalam kurun bulan Januari 2016 pada wilayah tersebut (Kemenkes RI 2016). Belum tersedia vaksin yang efektif untuk mencegah penularan virus ini maka cara yang paling efektif dilakukan adalah dengan pengendalian vektornya.

Di berbagai negara termasuk Indonesia, pengendalian Ae. aegypti masih sangat bergantung pada penggunaan insektisida. Insektisida yang paling banyak digunakan adalah insektisida dari golongan piretroid, seperti permetrin. Hal ini disebabkan karena keefektifannya tinggi, toksitas terhadap manusia relatif rendah, serta mudah terdegradasi sehingga tidak terakumulasi di lingkungan. Namun, penggunaan insektisida secara terus-menerus dalam jangka panjang telah banyak menimbulkan resistensi terhadap Ae. aegypti di banyak negara (Harris et al. 2010; Lopez et al. 2014).
Di Indonesia, resistensi Ae. aegypti terhadap insektisida sudah dilaporkan beberapa kali. Brengues et al. (2003) melaporkan bahwa Ae. aegypti dari daerah Semarang telah resisten 296 kali terhadap permetrin. Selanjutnya Ahmad et al. (2007) melaporkan bahwa Ae. aegypti strain Bandung dan Palembang telah resisten terhadap permetrin, masing masing sebesar 79,3 kali dan 23,7 kali. Perkembangan resistensi serangga terhadap insektisida merupakan suatu proses evolusi yang berkaitan dengan kemampuan genotip suatu populasi untuk bertahan hidup dan bereproduksi dalam lingkungannya. Resistensi terhadap insektisida terjadi karena insektisida bertindak sebagai agen penyeleksi pada populasi, yang akan membuat serangga yang mempunyai gen resisten tetap hidup dan akan diturunkan pada generasi berikutnya. Akibatnya, serangga resisten akan semakin bertambah, sedangkan yang rentan akan tereliminasi oleh insektisida (Ahmad 2011). Walaupun demikian, kecepatan serangga untuk mengembangkan resistensi terhadap insektisida tidak sama dan ditentukan antara lain oleh waktu perkembangan yang dibutuhkan oleh setiap generasi, jumlah keturunan, mobilitas, serta cara dan dosis penggunaan insektisida (Georghiou \& Taylor 1977).

Resistensi serangga terhadap insektisida merupakan hambatan utama dalam pengendalian serangga hama, termasuk vektor penyakit. Serangga yang telah resisten akan sulit dikendalikan walaupun dilakukan aplikasi berulang dan dengan penggunaan dosis yang tinggi. Akibatnya, pengendalian menjadi tidak efektif bahkan dapat terjadi ledakan populasi hama, biaya operasional meningkat, serta terjadinya kerusakan lingkungan. 
Oleh sebab itu, agar insektisida masih bermanfaat untuk mengendalikan hama, timbulnya resistensi harus dicegah atau diperlambat dengan pengelolaan resistensi pada populasi target melalui pengaturan bagaimana, kapan, dan senyawa kimia apa yang tepat digunakan.

Untuk mencegah atau memperlambat terjadinya resistensi, pemahaman tentang dinamika kecepatan evolusi resistensi pada saat ada atau tidak ada tekanan seleksi insektisida terhadap serangga perlu dipahami dengan baik. Selain itu, pemantauan status resistensi serangga terhadap suatu insektisida secara periodik sangat diperlukan sehingga tingkat dan perkembangan resistensi serangga terhadap insektisida tertentu dapat diketahui, sebagai acuan untuk menentukan tindakan pengendalian yang akan dilakukan.

Dalam penelitian ini dilakukan uji resistensi dengan menggunakan metode WHO untuk menentukan dan memperbaharui status resistensi larva Ae. aegypti dari beberapa daerah di Indonesia. Selain itu, dilakukan tekanan seleksi permetrin terhadap larva Ae. aegypti di laboratorium yang hasilnya dapat digunakan untuk memperkirakan tingkat perkembangan resistensi terhadap insektisida di lapangan. Hasil yang diperoleh dari penelitian ini secara umum dapat digunakan sebagai masukan untuk merancang strategi pengendalian serangga vektor yang lebih baik

\section{BAHAN DAN METODE}

\section{Asal strain dan perbanyakan nyamuk Ae. aegypti}

Larva Ae. aegypti strain lapangan dikumpulkan dan dikoleksi pada tahun 2011-2012 dari Palu, Makassar, Bandung, dan Bogor. Strain rentan yang digunakan sebagai pembanding berasal dari Vector Control Research Unit (VCRU), Universiti Sains Malaysia. Pemeliharaan dan perbanyakan nyamuk secara umum mengikuti metode Gerberc (1970). Serangga uji dipelihara di Laboratorium Toksikologi, Sekolah Ilmu dan Teknologi Hayati, Institut Teknologi Bandung pada suhu $24-27^{\circ} \mathrm{C}$, dan fotoperioda $12: 12$.

\section{Insektisida}

Insektisida yang digunakan adalah permetrin 92\% yang diperoleh dari PT Evespring Indonesia. Untuk uji larva digunakan permetrin $1 \%$, yang sebelumnya diencerkan dengan menggunakan aseton.

\section{Uji hayati}

Status resistensi ke empat strain lapangan dan strain rentan VCRU ditentukan dengan metode uji hayati larva standar WHO (WHO 2005). Uji pendahuluan dilakukan untuk menentukan selang konsentrasi yang digunakan pada uji pemantapan (uji lanjutan). Selanjutnya uji lanjutan dilakukan dengan menggunakan 25 individu larva instar empat awal dengan umur dan ukuran sama yang terdiri atas tiga kelompok ulangan. Larva uji didedahkan pada larutan permetrin 1\% sebanyak $250 \mathrm{ml}$ pada lima konsentrasi berbeda yang ditempatkan pada gelas kimia $500 \mathrm{ml}$. Kelompok kontrol hanya menggunakan aseton $1 \%$. Kematian larva ditentukan setelah 24 jam pendedahan. Larva dianggap mati adalah larva yang tidak bergerak walaupun telah disentuh, atau larva yang tidak mampu naik ke permukaan atau tidak menunjukkan reaksi menyelam saat air terganggu.

Tekanan seleksi permetrin dilakukan dengan prosedur yang sama pada uji hayati larva. Tekanan seleksi dilakukan terhadap semua strain lapangan maupun terhadap strain rentan/standar VCRU. Pendedahan dilakukan pada konsentasi sama, yaitu konsentrasi yang diperoleh pada konsentrasi letal $50\left(\mathrm{LC}_{50}\right)$. Larva lulus hidup selanjutnya dikembangkan untuk generasi selanjutnya. Tekanan seleksi dilakukan sampai lima generasi, namun strain Palu hanya mencapai generasi ke dua karena tingkat oviposisinya yang rendah dibandingkan dengan strain yang lain, sehingga jumlah serangga uji tidak mencukupi.

\section{Analisis data}

Mortalitas larva dianalisis dengan menggunakan program POLO PC (LeOra Software 2004) untuk menentukan $\mathrm{LC}_{50}$ dan $\mathrm{LC}_{90}$ dari masingmasing strain. Tingkat/rasio resistensi (RR) ditentukan dengan cara membandingkan nilai $\mathrm{LC}_{50}$ atau $\mathrm{LC}_{90}$ strain lapangan dengan nilai $\mathrm{LC}_{50}$ atau $\mathrm{LC}_{90}$ strain rentan VCRU. Pengaruh tekanan seleksi permetrin terhadap perkembangan tingkat resistensi pada setiap generasi dan strain ditentukan menggunakan formula Brown \& Payne (1998), dengan membandingkan Log $\mathrm{LC}_{50}$ generasi resistensi dikurangi $\log \mathrm{LC}_{50}$ parental dibandingkan dengan Log generasi yang diseleksi. 


\section{HASIL}

Resistensi larva Ae. aegypti terhadap permetrin

Hasil pengujian menunjukkan bahwa semua larva nyamuk Ae. aegypti strain lapangan telah resisten terhadap insektisida permetrin (Tabel 1), dengan tingkat resistensi $\left(\mathrm{RR}_{50}\right)$ berturut-turut 10,52 kali, 15,28 kali, 24,94 kali, dan 25,66 kali, masing masing untuk strain Makassar, Bogor, Palu, dan Bandung.

Tekanan seleksi permetrin dan perubahan tingkat resistensi larva Ae. aegypti

Pelaksanaan seleksi dilakuan pada ribuan larva Ae. aegypti instar empat awal menghasilkan kematian 46-51\%. Hasil penelitian (Tabel 2), menunjukkan bahwa setelah dilakukan tekanan seleksi pada konsentrasi $\mathrm{LC}_{50}$ permetrin terhadap larva Ae. aegypti di laboratorium selama lima generasi, terjadi kenaikan tingkat resistensi larva setiap generasi yang mendapatkan tekanan seleksi dibandingkan dengan parentalnya.

Kenaikan tingkat resistensi dari setiap generasi pada masing-masing strain berbeda-beda dari rendah sampai tinggi pada $F 1$, yaitu strain Bandung 1,6 kali, Makassar 1,6 kali, Palu 1,8 kali, VCRU 1,8 kali, dan tertinggi strain Bogor 1,9 kali walaupun peningkatannya tidak berbeda jauh dibandingkan dengan parentalnya. Namun pada F2, kenaikan tingkat resistensi lebih tinggi dan menunjukkan perbedaan yang signifikan dibandingkan parental dan F1. Demikian juga pada F3 terjadi peningkatan resistensi yang cukup tinggi dari masing-masing strain, seperti pada strain VCRU meningkat 8 kali, Bandung 5 kali, Makassar 5 kali, dan strain Bogor 5 kali dibandingkan dengan parentalnya. Tekanan seleksi dilakukan sampai pada F5, menghasilkan peningkatan tingkat resistensi yang semakin tinggi menjadi 18 kali pada strain VCRU, 9 kali pada Makassar, 6 kali pada Bogor, dan 5 kali pada strain Bandung.

Penelitian juga dilakukan untuk mengetahui tingkat resisistensi apabila tekanan seleksi dihentikan. Hasilnya menunjukkan bahwa kelompok kontrol yang tidak mendapatkan tekanan seleksi selama lima generasi (K) mengalami penurunan tingkat resistensi dibandingkan dengan parentalnya (F0) (Tabel 3). Penurunan tingkat resistensi bervariasi pada setiap strain, tertinggi pada strain Palu, yaitu 3 kali, Bandung 2 kali, Bogor 2 kali, VCRU 2 kali. Sedangkan penurunan tingkat resistensi pada generasi kelima tanpa tekanan seleksi permetrin, yang terendah adalah strain Makassar, yaitu hanya satu kali dibandingkan dengan parental.

Hasil seleksi larva Ae. aegypti terhadap permetrin pada beberapa generasi untuk parental (F0) menghasilkan nilai slope antara $(1,159 \pm$ $0,176-1,631 \pm 0,306)$, sedangkan untuk generasi kelima (F5) nilainya $(2,27 \pm 0,221-3,525 \pm$ $0,314)$. Nilai slope yang tertinggi diperoleh pada F3 Bandung 7,846 \pm 0,261 (Tabel 2).

\section{PEMBAHASAN}

Bila mengacu kepada pengelompokan rasio resistensi yang disusun oleh Lee \& Lee (2004), maka semua strain yang diperoleh dari lapangan termasuk pada kategori resisten tinggi (nilai $\left.\mathrm{RR}_{50}>10\right)$. Tingginya tingkat resistensi terhadap permetrin kemungkinan disebabkan karena permetrin telah digunakan secara luas sejak tahun 1980an, baik untuk pengendalian hama pertanian,

Tabel 1. Tingkat resistensi larva Aedes aegypti strain Bandung, Bogor, Makassar, dan Palu terhadap permetrin

\begin{tabular}{|c|c|c|c|c|c|c|c|c|}
\hline \multirow{2}{*}{ Strain } & \multirow{2}{*}{$\mathrm{N}$} & $\mathrm{LC}_{50}$ & $95 \%$ (SK) & \multirow{2}{*}{$\mathrm{RR}_{50}$} & $\mathrm{LC}_{90}$ & $95 \%(\mathrm{SK})$ & \multirow{2}{*}{$\mathrm{RR}_{90}$} & \multirow{2}{*}{ Slope $\pm \mathrm{SE}$} \\
\hline & & & (ppm) & & & (ppm) & & \\
\hline VCRU/S* & 376 & 0,08 & $0,065-0,093$ & - & 0,327 & $0,259-0,452$ & - & $2,071 \pm 0,208$ \\
\hline $\mathrm{BDG} / \mathrm{R}^{*}$ & 346 & 2,03 & $1,523-2,744$ & 25,658 & 25,865 & $13,458-83,115$ & 79,1 & $1,159 \pm 0,176$ \\
\hline $\mathrm{BGR} / \mathrm{R} *$ & 300 & 1,21 & $0,753-2,335$ & 15,278 & 7,368 & $3,354-53,268$ & 22,53 & $1,631 \pm 0,306$ \\
\hline $\mathrm{MKS} / \mathrm{R}^{*}$ & 373 & 0,83 & $0,462-1,214$ & 10,519 & 9,178 & $4,989-33,232$ & 28,07 & $1,229 \pm 0,171$ \\
\hline PLW/ R* & 375 & 1,97 & $1,467-3,075$ & 24,937 & 13,643 & $7,144-40,630$ & 35,35 & $1,525 \pm 0,207$ \\
\hline
\end{tabular}

S*: strain rentan/standar; R*: strain resisten/lapangan.

VCRU: Vector Control Research Unit; BDG: Bandung; BGR: Bogor; MKS: Makassar; PLW: Palu.

$\mathrm{LC}_{50 / 90}(24)$ : lethal concentration yang mengakibatkan kematian 50\% atau 90\% larva Ae. aegypti pada 24 jam pengamatan. $\mathrm{RR}$ : rasio resistensi; $\mathrm{RR}_{50}=\mathrm{LC}_{50} \mathrm{R} * \mathrm{LC}_{50} \mathrm{~S} ; \mathrm{RR}_{90}=\mathrm{LC}_{90} \mathrm{R} * / \mathrm{LC}_{90} \mathrm{~S}$. 
Tabel 2. Tingkat resistensi larva Aedes aegypti setelah tekanan seleksi permetrin pada lima generasi strain Bandung, Bogor, Makassar, Palu, dan VCRU

\begin{tabular}{|c|c|c|c|c|c|c|c|}
\hline Strain & Generasi & $\mathrm{N}$ & $\mathrm{LC}_{50}(\mathrm{ppm})$ & 95\% (C.L) & Slope $\pm \mathrm{SE}$ & $\mathrm{RR}_{50}$ & $\mathrm{R}$ \\
\hline VCRU/S & & 376 & 0,079 & $0,259-0,452$ & $2,071 \pm 0,208$ & 1 & \\
\hline \multirow[t]{6}{*}{$\mathrm{BDG} / \mathrm{R}$} & F0 & 332 & 2,027 & $1,523-2,744 \mathrm{a}$ & $1,159 \pm 0,176$ & 25,658 & 0,00 \\
\hline & F1 & 373 & 3,187 & $2,391-4,854 \mathrm{ab}$ & $1,947 \pm 0,216$ & 40,342 & 1,57 \\
\hline & F2 & 375 & 6,003 & $5,226-7,010 \mathrm{~b}$ & $2,754 \pm 0,262$ & 75,987 & 2,96 \\
\hline & F3 & 375 & 11,083 & $9,690-2,820 \mathrm{~d}$ & $7,846 \pm 0,870$ & 140,29 & 5,47 \\
\hline & F4 & 375 & 8,326 & $7,697-8,997 \mathrm{c}$ & $2,807 \pm 0,261$ & 105,39 & 4,11 \\
\hline & F5 & 375 & 10,043 & $8,278-12,199 \mathrm{c}$ & $3,032 \pm 0,251$ & 127,13 & 4,95 \\
\hline \multirow[t]{6}{*}{$\mathrm{BGR} / \mathrm{R}$} & F0 & 300 & 1,207 & $0,753-2,335 \mathrm{a}$ & $1,631 \pm 0,306$ & 15,278 & 0,00 \\
\hline & F1 & 373 & 2,326 & $1,965-2,774 \mathrm{a}$ & $1,966 \pm 0,190$ & 29,443 & 1,93 \\
\hline & $\mathrm{F} 2$ & 356 & 3,569 & $2,850-4,676 \mathrm{~b}$ & $2,011 \pm 0,208$ & 45,177 & 2,96 \\
\hline & F3 & 375 & 4,626 & $3,822-5,668 \mathrm{~b}$ & $2,911 \pm 0,245$ & 58,557 & 3,83 \\
\hline & F4 & 373 & 6,784 & $5,875-7,876 \mathrm{c}$ & $4,577 \pm 0,418$ & 85,873 & 5,62 \\
\hline & F5 & 375 & 7,468 & $6,205-9,020 \mathrm{c}$ & $2,744 \pm 0,229$ & 94,532 & 6,19 \\
\hline \multirow[t]{6}{*}{ MKS/R } & F0 & 373 & 0,831 & $0,462-1,214 \mathrm{a}$ & $1,229 \pm 0,171$ & 10,519 & 0,00 \\
\hline & F1 & 375 & 1,368 & $1,027-2,005 \mathrm{a}$ & $1,099 \pm 0,167$ & 17,316 & 1,65 \\
\hline & $\mathrm{F} 2$ & 375 & 3,456 & $2,883-4,330 \mathrm{~b}$ & $2,090 \pm 0,228$ & 43,747 & 4,16 \\
\hline & F3 & 375 & 4,118 & $3,551-4,823 \mathrm{~b}$ & $2,340 \pm 0,211$ & 52,127 & 4,96 \\
\hline & F4 & 375 & 6,191 & $5,248-7,413 \mathrm{c}$ & $2,694 \pm 0,238$ & 78,367 & 7,45 \\
\hline & F5 & 375 & 7,738 & $6,601-9,287 \mathrm{c}$ & $2,273 \pm 0,221$ & 97,949 & 9,31 \\
\hline \multirow[t]{6}{*}{ VCRU/R } & F0 & 371 & 0,135 & $0,086-0,204 \mathrm{a}$ & $1,541 \pm 0,178$ & 1,709 & 0,00 \\
\hline & F1 & 375 & 0,249 & $0,189-0,373 \mathrm{a}$ & $1,800 \pm 0,208$ & 3,152 & 1,84 \\
\hline & F2 & 375 & 0,677 & $0,533-0,972 \mathrm{~b}$ & $1,643 \pm 0,182$ & 8,57 & 5,02 \\
\hline & F3 & 379 & 1,135 & $0,960-1,369 \mathrm{~b}$ & $2,021 \pm 0,199$ & 14,37 & 8,41 \\
\hline & F4 & 375 & 1,455 & $1,228-1,746 \mathrm{~b}$ & $1,952 \pm 0,191$ & 29,69 & 10,78 \\
\hline & F5 & 375 & 2,405 & $2,142-2,709 \mathrm{c}$ & $3,528 \pm 0,314$ & 30,443 & 17,815 \\
\hline \multirow[t]{3}{*}{ PLW/R } & F0 & 375 & 1,97 & $1,467-3,075 \mathrm{a}$ & $1,525 \pm 0,207$ & 24,94 & 0,00 \\
\hline & F1 & 338 & 3,576 & $2,934-4,513 \mathrm{a}$ & $2,218 \pm 0,225$ & 45,27 & 1,82 \\
\hline & F2 & 370 & 6,557 & $5,579-7,873 \mathrm{~b}$ & $3,187 \pm 0,313$ & 83 & 3,33 \\
\hline
\end{tabular}

VCRU/S: Vector Control Research Unit standar; VCRU/R: Vector Control Research Unit yang diseleksi; BDG: Bandung; BGR: Bogor; MKS: Makassar; PLW: Palu.

$\mathrm{LC}_{50}$ (24): lethal cocentration yang menyebabkan kematian $50 \%$ larva Ae. aegypti pada 24 jam pengamatan; $\mathrm{RR}$ : rasio resistensi; $\mathrm{RR}_{50}=\mathrm{LC}_{50} \mathrm{R}^{*} / \mathrm{LC}_{50} \mathrm{~S}^{*}$.

$\mathrm{R}=$ tingkat resistensi $=\mathrm{LC}_{50} \mathrm{Fx} / \mathrm{F} 0, \mathrm{X}=\mathrm{F} 1, \mathrm{~F} 2, \mathrm{~F} 3, \mathrm{~F} 4$, dan $\mathrm{F} 5$ (Generasi ke satu, ke dua, ke tiga, ke empat, dan ke lima yang mendapat tekanan seleksi permetrin konsentrasi pada $\mathrm{LC}_{50}$. F0: parental; $\mathrm{N}$ : total larva yang digunakan. Nilai yang diikuti oleh huruf abjad berbeda dalam kolom yang sama adalah berbeda nyata pada selang kepercayaan $95 \%$.

peternakan, permukiman, serta dalam program ke- kota, selain latar belakang genetik dan variasi sehatan masyarakat untuk pengendalian nyamuk. ekologis.

Perbedaan tingkat resistensi pada setiap strain,

Khusus untuk strain Bandung, menarik kemungkinan hal ini disebabkan oleh perbedaan tingkat penggunaan dan jenis insektisida di tiap sekali melihat bahwa tingkat resistensi terhadap permetrin yang diperoleh dari penelitian ini, yaitu 
Tabel 3. Tingkat resistensi larva Aedes aegypti parental dan generasi ke lima yang tidak mendapat tekanan seleksi permetrin $(\mathrm{K})$

\begin{tabular}{|c|c|c|c|c|c|c|c|}
\hline \multirow{2}{*}{ Strain } & \multirow{2}{*}{ Generasi } & \multirow{2}{*}{$\mathrm{N}$} & $\mathrm{LC}_{50}$ & 95\% (SK) & \multirow{2}{*}{$\mathrm{RR}_{50}$} & \multirow{2}{*}{ Slope $\pm \mathrm{SE}$} & \multirow{2}{*}{$-\mathrm{R}$} \\
\hline & & & \multicolumn{2}{|c|}{$(\mathrm{ppm})$} & & & \\
\hline VCRU/S* & & 376 & 0,079 & $0,065-0,093$ & & $2,071 \pm 0,208$ & \\
\hline \multirow[t]{2}{*}{ VCRU** } & F0 & 375 & $0,135 \mathrm{a}$ & $0,086-0,204$ & - & $1,429 \pm 0,190$ & \\
\hline & $\mathrm{K}$ & 376 & $0,079 \mathrm{a}$ & $0,065-0,093$ & & $2,071 \pm 0,208$ & 1,709 \\
\hline \multirow[t]{2}{*}{ BDG** } & F0 & 346 & $2,027 \mathrm{a}$ & $1,523-2,744$ & 41,367 & $1,159 \pm 0,176$ & \\
\hline & K & 375 & $0,846 \mathrm{~b}$ & $0,675-1,016$ & 10,709 & $2,038 \pm 0,219$ & 2,396 \\
\hline \multirow[t]{2}{*}{$\mathrm{BGR}^{* *}$} & F0 & 300 & $1,207 \mathrm{a}$ & $0,753-2,335$ & 24,633 & $1,631 \pm 0,306$ & \\
\hline & K & 372 & $0,649 \mathrm{~b}$ & $0,555-0,769$ & 8,215 & $2,246 \pm 0,216$ & 1,860 \\
\hline \multirow[t]{2}{*}{ MKS** } & F0 & 373 & $0,831 \mathrm{a}$ & $0,462-1,214$ & 23,777 & $1,229 \pm 0,171$ & \\
\hline & K & 375 & $0,763 \mathrm{a}$ & $0,579-0,948$ & 9,658 & $1,626 \pm 1,191$ & 1,089 \\
\hline \multirow{2}{*}{ PLW** } & F0 & 375 & $1,970 \mathrm{a}$ & $1,467-3,075$ & 40,204 & $1,525 \pm 0,207$ & \\
\hline & K & 375 & $0,716 \mathrm{~b}$ & $0,557-0,964$ & 9,063 & $1,231 \pm 0,168$ & 2,751 \\
\hline
\end{tabular}

*: strain standar; **: strain yang tidak mendapatkan seleksi selama lima generasi.

VCRU/S*: Vector Control Research Unit standar; VCRU: Vector Control Research Unit; BDG: Bandung; BGR: Bogor; MKS: Makassar; PLW; Palu.

$\mathrm{K}$ : kontrol yang tidak mendapatkan seleksi selama lima generasi; F0: parental.

$-\mathrm{R}$ = penurunan tingkat resistensi $=\mathrm{LC}_{50} \mathrm{~F} 0 / \mathrm{LC}_{50} \mathrm{~K} ; \mathrm{RR}_{50}=\mathrm{LC}_{50} * * / \mathrm{LC}_{50} *$. Nilai yang diikuti oleh huruf abjad berbeda dalam kolom yang sama adalah berbeda nyata pada selang kepercayaan $95 \%$.

$\mathrm{RR}_{90}$ sebesar 79,1 kali, nilainya sama dengan yang pernah dilaporkan pada tahun 2006, yaitu 79,3 kali (Gerberc 1970). Tidak meningkatnya status resistensi strain Bandung dalam kurun waktu 2006-2012, diperkirakan karena Ae. aegypti Bandung tidak memperoleh tekanan seleksi yang kuat dari permetrin atau karena penggunaan insektisida jenis lain, walau tingkat resistensi tetap tinggi.

Secara umum status resistensi nyamuk $A e$. aegypti yang dilaporkan dalam penelitian ini $\left(\mathrm{RR}_{50} 10,52-25,66\right.$ kali, dan $\mathrm{RR}_{90} 22,53-79,1$ kali), cukup tinggi jika dibandingkan dengan negara lain. Sebagai contoh, di Thailand Ae. aegypti telah resisten terhadap permetrin dengan nilai $\mathrm{RR}_{90}{ }^{13}-$ 72 (Ponlawat et al. 2005), sedangkan di Malaysia mempunyai nilai $\mathrm{RR}_{50} 1,86-5,57$ (Wan-Norafikah et al. 2010).

Terjadinya peningkatan resistensi akibat seleksi dari waktu ke waktu sampai pada lima generasi hingga 17,8 kali nampaknya karena insektisida telah menyeleksi individu rentan, dan yang berhasil hidup adalah individu yang resisten terhadap insektisida. Hal serupa dilakukan oleh Kumar et al. (2002) melalui tekanan seleksi insektisida selama 40 generasi pada larva yang menghasilkan tingkat resistensi sebesar 703 kali, demikian juga yang dilakukan oleh Chang et al. (2012), pada 46 generasi telah terjadi peningkatan resistensi 400 kali lipat. Hasil yang menarik ditunjukkan bahwa perkembangan resistensi pada strain rentan VCRU lebih cepat dibandingkan dengan strain lapangan. Hal ini diduga karena alel resisten untuk fitness yang lebih baik sudah tersedia dalam populasi rentan VCRU dan dapat segera terseleksi dengan cara seleksi laboratorium. Lebih lanjut fenomena yang terjadi dijelaskan oleh David et al. (2014) bahwa walaupun seleksi di laboratorium tidak sama dengan proses adaptasi yang terjadi di alam, tetapi cara seleksi di laboratorium dari strain rentan memungkinkan sedikitnya variasi genetis yang disebabkan oleh latar belakang genetik yang berbeda.

Penurunan tingkat resistensi pada kelima strain tanpa seleksi insektisida bervariasi. Pada strain VCRU dan Makassar, penurunan tingkat resistensinya tidak signifikan dibandingkan dengan parentalnya. Sedangkan pada strain yang memiliki tingkat resistensi cukup tinggi dibandingkan dengan VCRU dan Makassar, seperti Bandung, Bogor, dan Palu, terjadi penurunan tingkat resistensi yang signifikan. Hal ini nampaknya terjadi karena adanya cost yang berhubungan dengan resistensi yang mempengaruhi fitness serangga uji (Rahayu 2011). Chang et al. (2012) juga melaporkan bahwa penurunan resistensi permetrin secara bertahap ke tingkat rentan yang terjadi setelah 15 generasi tanpa seleksi di laboratorium (Chang et al. 2012). Hal ini dapat terjadi karena aplikasi insektisida yang dihentikan 
akan memberikan kesempatan bagi genotip rentan untuk bertahan hidup. Genotip rentan berasal dari pewarisan sifat gen resesif resisten heterozigot yang dihasilkan oleh perkawinan silang antara individu yang rentan dan resisten (Georghiou \& Taylor 1977).

Setiap individu dalam suatu populasi memiliki kemampuan berbeda untuk menanggapi adanya tekanan seleksi insektisida. Homogenitas individu dalam suatu populasi untuk menanggapi tekanan tersebut dapat dilihat dari nilai slope. Semakin rendah nilai slope memberikan indikasi bahwa individu-individu dalam suatu populasi semakin bervariasi dalam merespon suatu tekanan insektisida, dan sebaliknya semakin tinggi nilai slope maka populasi tersebut semakin homogen (Hansen et al. 2005).

Pada penelitian ini nilai slope dari setiap generasi pada lima populasi larva Ae. aegypti berbeda antara generasi dan strain. Nilai slope dari masing-masing strain cenderung lebih tinggi pada turunannya dibandingkan dengan parentalnya. Nilai slope yang tertinggi rata-rata berada pada F5 pada masing-masing strain. Nilai slope pada parental lebih rendah kemungkinan disebabkan oleh sebagian besar populasi yang terseleksi adalah individu rentan dari populasi yang resisten (Georghiou \& Taylor 1977). Hal ini diduga bahwa respon yang lebih homogen pada F5 dan F3 Bandung terhadap insektisida dan juga larva lebih sensitif terhadap perubahan konsentrasi permetrin yang diberikan.

Berdasarkan hasil yang diperoleh dari penelitian ini serta laporan dari luar negeri maka sebaiknya untuk Indonesia, penggunaan piretroid, terutama permetrin perlu diganti (dirotasi) dengan insektisida lain yang mempunyai cara kerja yang berbeda dengan piretroid. Dengan cara ini terjadinya resistensi Ae. aegypti terhadap permetrin ke tingkat yang lebih tinggi dan menyebar ke daerah lain di Indonesia dapat dicegah atau dikurangi.

\section{KESIMPULAN}

Hasil penelitian menunjukkan bahwa, larva Ae. aegypti yang dikoleksi dari empat kota di Indonesia (Bandung, Bogor, Makassar, dan Palu) telah resisten dengan status tinggi $\left(\mathrm{RR}_{50} 10,5-25,7\right.$ dan $\left.\mathrm{RR}_{90} 22,5-79,1\right)$ terhadap permetrin, dengan tingkat resistensi tertinggi pada strain Bandung dan terendah pada strain Makassar. Tekanan seleksi pada konsentrasi $\mathrm{LC}_{50}$ permetrin selama lima generasi menunjukkan peningkatan resistensi 1-15 kali pada generasi ke lima dibandingkan dengan parental. Sebaliknya, pada strain yang mempunyai tingkat resistensi tinggi, pemeliharaan sampai generasi kelima tanpa perlakuan insektisida menunjukkan penurunan tingkat resistensi.

\section{UCAPAN TERIMA KASIH}

Terima kasih ditujukan kepada Dinas Pendidikan dan Kebudayaan Daerah Provinsi Sulawesi Tengah yang telah memberikan beasiswa kepada penulis pertama untuk menyelesaikan program magister di Institut Teknologi Bandung. Para penulis juga menyampaikan terima kasih kepada PT Evespring Indonesia yang telah menyediakan insektisida permetrin yang digunakan dalam penelitian.

\section{DAFTAR PUSTAKA}

Ahmad I, Astari S, Tan MI. 2007. Resistance of Aedes aegypti (Diptera: Culicidae) in 2006 to pyrethroid insecticides in Indonesia and its association with oxidase and esterase levels. Pakistan Journal of Biological Sciences 10:3688-3692. doi: http:// dx.doi.org/10.3923/pjbs.2007.3688.3692.

Ahmad I. 2011. Adaptasi Serangga dan Dampaknya terhadap Kehidupan Manusia, Majelis Guru Besar, Institut Teknologi Bandung. Bandung: Institut Teknologi Bandung.

Brengues C, Hawkes NJ, Chandre F, McCarroll L, Duchon S, Guillet P, Maguin S, Morgan JC, Hemingway J. 2003. Pyrethroid and DDT crossresistance in Aedes aegypti correlated with novel mutations in the voltage-gated sodium channel gene. Medical and Veterinary Entomology 17:87-94. doi:http://dx.doi.org/10.1046/j.13652915.2003.00412.x.

Brown TM, Payne GT. 1998. Experimental selection for insecticide resistance. Journal of Economic Entomology 8:49-56.

Chang C, Huang XY, Chang PC, Wu HH, Dai SM. 2012. Inheritance and stability of sodium channel mutations associated with permethrin 
knockdown resistance in Aedes aegypti. Journal of Pesticide Biochemistry and Physiology 30:1-9. doi: http://dx.doi.org/10.1016/j.pestbp. 2012.06.003.

David JP, Faucon F, Chandor-Proust A, Poupardin R, Riaz MA, Bonin A, Navratil V, Reynaud. 2014. Comparative analysis of response to selection with three insecticide in the dengue mosquito Aedes aegypti using mRNA sequencing. BMC Genomics 15:174. doi: http://dx.doi.org/10.1186/ 1471-2164-15-174.

Georghiou G, Taylor CE. 1977. Genetic and biological influences in the evolution of insecticide resistance. Journal of Economic Entomology 70:319-323. doi: http://dx.doi.org/10.1093/jee/ 70.3.319.

Gerberc EJ. 1970. Manual for Mosquito Rearing and Experimental Techniques. AMCA Bulletin No. 05. Baltimore: American Mosquito Control Association Inc.

Hansen KK, Kristensen M, Jensen KMV. 2005. Correlation of a resistance associated $R d l$ mutation in the German cockroach, Blattella germanica (L.), with persistent dieldrin resistance in two Danish field populations. Pest Management Science 61:749-753. doi: http:// dx.doi.org/10.1002/ps.1059.

Harris AF, Rajatileka S, Ranson H. 2010. Pyrethroid resistance in Aedes aegypti from Grand Cayman. American Journal of Tropical Medecine and Hygiene 83:277-284. doi: http://dx.doi.org/10. 4269/ajtmh.2010.09-0623.

Kementerian Kesehatan Republik Indonesia [Kemenkes RI]. 2015. Demam berdarah biasanya mulai meningkat di Januari. Available at: http:// www.depkes.go.id/article/view/15011700003/ demam-berdarah-biasanya-mulai-meningkat-dijanuari.html [diakses 12 Februari 2016].

Kementerian Kesehatan Republik Indonesia. [Kemenkes RI]. 2016. Wilayah KLB DBD ada di 11 Kabupaten/Kota. Available at: http:// www.depkes.go.id/article/view/16020900001/ wilayah-klb-dbd-ada-di-11-kabupaten-kota.html [diakses 12 Februari 2016].
Kumar S, Thomas A, Sahgal A, Verma A, Samuel T, Pillai MKK. 2002. Effect of the synergist, piperonyl butoxide, on the development of deltamethrin resistance in yellow fever mosquito, Aedes aegypti L. (Diptera: Culicidae). Archives of Insect Biochemistry and Physiology 50:1-8. doi: http://dx.doi.org/10.1002/arch.10021.

Lee LC, Lee CY. 2004. Insecticide resistance profiles and possible underlying mechanisms in german cockroaches, Blattella germanica (Linnaeus) (Dictyoptera: Blattellidae) from Peninsular Malaysia. Medical Entomological Zoology 55: 77-93. doi: http://dx.doi.org/10.7601/mez.55.77_1.

LeOra Software. 2004. POLO-PC: Probit and Logit Analysis, LeOra Software, California.

Lopez B, Ponce G, Gonzalez JA, Gutierrez SM, Villanueva OK, Gonzalez G, Bobadilla C, Rodriguez IP, Black WC, Flores AE. 2014. Susceptibility to chlorpyrifos in pyrethroidresistant populations of Aedes aegypti (Diptera: Culicidae) from Mexico. Journal of Medical Entomolology 51:644-9. doi: http://dx.doi.org/ 10.1603/ME13185.

Ponlawat A, Scott JG, Harrington LC. 2005. Insecticide susceptibility of Aedes aegypti and Aedes albopictus across Thailand. Journal of Medical Entomolology 42:821-5. doi: http://dx.doi.org/ 10.1603/0022-2585(2005)042[0821:ISOAAA]2 .0.CO;2.

Rahayu R. 2011. Status dan Mekanisme Resistensi serta Fitness Blattella germanica L. (Dyctioptera: Blattellidae) Asal Bandung, Jakarta dan Surabaya terhadap Propoksur, Permetrin dan Fipronil. PhD Thesis. Bandung: Institut Teknologi Bandung.

Wan-Norafikah O, Nazni WA, Lee HL, ZainolAriffin P, Sofian-Azirun M. 2010. Permethrin resistance in Aedes aegypti (Linnaeus) collected from Kuala Lumpur, Malaysia. Journal of AsiaPacific Entomology 13:175-182. doi: http:// dx.doi.org/10.1016/j.aspen.2010.03.003.

World Health Organization. 2005. Guidelines for Laboratory and Feld Testing of Mosquito Larvicides. Geneva: World Health Organization 